\title{
Serum Clusterin as a Diagnostic Tool for HCV Related Hepatocellular Carcinoma
}

\author{
ELHAM O. HAMED, M.D.; TAMER M. ABD EL-LATEF, M.D.; AHMED S. MAHMOUD, M.D. and \\ KATREN Y. FAHEM, M.Sc.
}

The Department of Clinical and Chemical Pathology, Faculty of Medicine, Sohag University

\begin{abstract}
Background: Hepatocellular carcinoma (HCC) is considered one of the major malignant tumors in the world. The number of cases increases every years and HCC almost always has a fulminant course with grave prognosis.

Aim of Study: Was to evaluate the clinical use of serum clusterin levels as a diagnostic tool for HCC with hepatitis C virus related cirrhosis.

Subjects and Methods: A total of 100 subjects, 80 patients and 20 healthy controls were enrolled in this study. Patients were divided into 2 groups; group I: (30 patients) with HCV related liver cirrhosis, group II: (50 patients) with hepatocellular carcinoma. Serum levels of alpha fetoprotein (AFP) and clusterin (CLU) were measured. Alpha fetoprotein based on Chemiluminescent microparticle immunoassay (CMIA). Serum CLU concentration was performed using enzyme linked immunosorbent assay technique (ELISA).
\end{abstract}

Results: The mean values of serum clusterin increase significantly among HCC patients than controls and cirrhotic patients. The cirrhotic patients show significant decrease than controls group. The sensitivity and specificity for clusterin was $72.5 \%$ and $92 \%$ and for AFP was $77.3 \%$ and $100 \%$, respectively. The AUC for clusterin was $0.8(p<0.001)$ compared with $0.9(p<0.001)$ for AFP. The combined parallel approach improved the diagnostic sensitivity to $96.5 \%$. We found positive correlation between AFP and sCLU ( $r=0.31$ and $p=0.003$ ).

Conclusion: Serum CLU levels should be a useful potential biomarker for HCC diagnosis.

Key Words: Hepatitis C virus - Liver cirrhosis - Hepatocellular carcinoma.

\section{Introduction}

HEPATOCELLULAR carcinoma (HCC) is the most prevalent primary malignant tumor of the liver and is considered one of the most prevalent malignant diseases in the world [1]. Hepatocellular carcinoma is one of the most common cancerrelated deaths in the world [2]. The multiple etio-

Correspondence to: Dr. Elham O. Hamed,

E-Mail: elhamomar@yahoo.com pathogenic factors involved include chronic hepatitis $\mathrm{B}$ or $\mathrm{C}$ virus (HBV or HCV) infection [3,4]. In the Egyptian population, about $90 \%$ of $\mathrm{HCC}$ cases were attributed to $\mathrm{HCV}$ [5]. Hepatitis $\mathrm{C}$ virus is a global disease, estimated to be around 3\% worldwide, Egypt has the highest prevalence of HCV, which was estimated to be more than $15 \%$ [6] About $20 \%-30 \%$ of $\mathrm{HCV}$ patients develop cirrhosis after 20-30 years of disease [7]. The rate of progression to cirrhosis depends on the natural history of $\mathrm{HCV}$ infection, host related and virus related factors $[8]$. Cirrhotic patients may develop hepatocellular carcinoma within 5 years in up to $20 \%$ of patients [9] . Clusterin (CLU) is considered a molecular chaperone responsible for aiding protein folding of secreted proteins, can be produced under the perturbation of many physical and chemical factors [10] . Clusterin (apolipoprotein $\mathrm{J}$ ) is a 75$80 \mathrm{kDa}$ disulfide-linked heterodimeric protein associated with the clearance of cellular debris and apoptosis [11] . Clusterin has been reported to play a significant role in tumorigenesis [12] . Clusterin gene is encoded on chromosome 8 . Two CLU protein isoforms are present in human cells: A nuclear form (nCLU), proapoptotic, and a secretory form (sCLU) that is prosurvival [13]. The predominant SCLU expression was located in the endoplasmic reticulum of certain tumor cells. Circulating sCLU has been shown to be a valuable marker for diagnosis and surveillance of HCC $[\mathbf{1 4 , 1 5}]$. So we aimed to evaluate the clinical use of serum clusterin levels as a diagnostic tool for HCC with hepatitis $\mathrm{C}$ virus related cirrhosis.

\section{Subjects and Methods}

Subjects:

This study was a case control study conducted in clinical pathology department, Sohag University Hospitals during the period from November 2016 
to March 2018. It was approved by faculty committee for research ethics. Patients who participated in this study gave informed consent.

This study included 100 subjects, 80 patients and 20 healthy controls. Patients were divided into two groups. Group I: (30 patients) with HCV related liver cirrhosis, they were 22 males and 8 females with age range from $45-62$ years and a mean age of 53.2 \pm 4.1 years. Group II: (50 patients) with hepatocellular carcinoma who fulfilled the following criteria according to recommendations of Amer ican Association for the Study of Liver Diseases (AASLD) practice guidelines: Nodules larger than $1 \mathrm{~cm}$ found on ultrasound screening of a cirrhotic liver confirmed by triphasic CT scan or dynamic contrast enhanced MRI with typical appearance of HCC [16]. The age of the patients ranged from 4568 years with a mean age of $54.7 \pm 5.2$ years. They were 38 males and 12 females. According to the Milan criteria we subdivided group II to early cases (IIA) those who either have one lesion smaller than $5 \mathrm{~cm}$, up to 3 lesions smaller than $3 \mathrm{~cm}$, no extrahepatic manifestations, no vascular invasion, (15) patients. Late cases (IIB) not fulfilled the previous criteria, (35) patients. Controls involved 20 apparently healthy individuals selected to be matched for age and gender to patient groups (HCV antibody negative individuals).

Exclusion criteria were patients who had serological evidence of hepatitis B or human immunodeficiency virus infection, history of current alcohol and/or drug abuse, patients with history of prior anti-HCV treatment and treatment for HCC (Percutaneous ethanol injection or radiofrequency ablation).

\section{Methods:}

Ten $\mathrm{ml}$ venous blood was obtained from each subject in the morning after a 12 hour overnight fast, in the appropriate vacutainers provided. EDTA samples were subjected to complete blood picture on cell Dyne-3700 fully automated cell counter Abbot Diagnostics, German. The Na-citrated samples were used for determination of PT on SYSMEX fully automated system Dade Behring, German. Fasting serum glucose, renal function tests and liver function tests were determined by Cobas 311, fully automated chemical autoanalyzer (Roche/ Hitachi cobas c systems, Japan). HBsAg, anti$\mathrm{HCV}$ antibodies and serum AFP were measured using ARCHITECT Abbott Germany Diagnostics Division, Chicago) based on Chemiluminescent microparticle immunoassay (CMIA). Serum CLU concentration was performed using the quantikine ELISA human clusterin immunoassay. The test principle was quantitative sandwich enzyme linked immunosorbent assay technique. A monoclonal antibody specific for clusterin has been precoated onto a microplate. Standards and samples were pipetted into the wells and clusterin was bound by the immobilized antibody. After washing away any unbound substances, an enzyme linked monoclonal antibody specific for clusterin was added to the wells. Following a wash to remove any unbound antibody enzyme reagent, a substrate solution was added to the wells and color develops in proportion to the amount of clusterin. Then the color was stopped and the intensity of the color was measured.

\section{Statistical analysis:}

The data were analyzed by SPSS version 16 . The data are presented as mean \pm standard deviation (SD) and range. The differences between groups were compared by $t$-test and ANOVA test. To determine the optimal cutoff value for clusterin and AFP in the diagnosis of HCC, receiver operating characteristic (ROC) curves were constructed. The area under the curve (AUC) was calculated. For sensitivity and specificity, positive predictive value and negative predictive value were also determined. Linear relationship was determined using Pearson's correlation coefficient. A $p$-value which considered statistically significant was $<0.05$.

\section{Results}

The baseline demographic and laboratory variables of the studied groups were demonstrated in Table (1). Hepatocellular carcinoma patients showed significantly higher mean values of ALT, AST, bilirubin, ALP, prothrombin time, but significantly lower mean values for TP, albumin, RBCs, hemoglobin and platelets than controls. HCC patients showed significantly higher mean values of ALT, and ALP, but significantly lower mean values TP and albumin than cirrhotic group.

HCC patients showed significantly higher mean values of AFP than controls and cirrhotic patients. There is no difference in AFP between subgroup of HCC patients. The mean values of serum clusterin increase significantly among HCC patients than controls and cirrhotic patients, but the cirrhotic patients show significant decrease than controls group (Tables 2,3).

The ROC curves were plotted to identify a cutoff value that would best distinguish HCC from liver cirrhosis patients (Fig. 1). The optimal cutoff values for serum clusterin and serum AFP were $135 / \mathrm{m}$ and $137 \mathrm{ng} / \mathrm{mL}$, respectively. The sensi- 
tivity and specificity for clusterin was $72.5 \%$ and $92 \%$ and for AFP was $77.3 \%$ and $100 \%$, respectively. The positive predictive value (PPV) and negative predictive value (NPV) was $86.1 \%$ and $77.6 \%$ for clusterin and $100 \%$ and $83.3 \%$ for AFP, respectively (Table 4$)$. The AUC for clusterin was $0.8(p<0.001)$ compared with $0.9(p<0.001)$ for
AFP. The combined parallel approach improved the diagnostic sensitivity to $96.5 \%$ and negative predictive value to $96.7 \%$ over the single use of serum AFP in HCC cases, but decreased the specificity to reach $89 \%$ and positive predictive value to $88.5 \%$. We found positive correlation between AFP and $\mathrm{sCLU}(r=0.31$ and $p=0.003)$.

Table (1): Baseline demographic and laboratory characteristics of the study groups.

\begin{tabular}{|c|c|c|c|c|c|c|}
\hline \multirow{2}{*}{ Variables } & \multirow{2}{*}{$\begin{array}{c}\text { Group I } \\
\text { LC }(n=30) \\
\text { Mean } \pm \text { SD }\end{array}$} & \multirow{2}{*}{$\begin{array}{c}\text { Group II } \\
\text { HCC }(n=50) \\
\text { Mean } \pm \text { SD }\end{array}$} & \multirow{2}{*}{$\begin{array}{c}\text { Group III } \\
\text { Control }(n=20) \\
\text { Mean } \pm \text { SD }\end{array}$} & \multicolumn{3}{|c|}{$p$-value } \\
\hline & & & & $p_{1}$ & $p_{2}$ & $p_{3}$ \\
\hline Age & $53.2 \pm 4.1$ & $54.7 \pm 5.2$ & $53.8 \pm 5.5$ & - & - & - \\
\hline Sex n: M:F & $22: 8$ & $38: 12$ & $10: 10$ & & & \\
\hline R. glucose $(\mathrm{mg} / \mathrm{dl})$ & $105.1 \pm 9.7$ & $104.26 \pm 11.1$ & $108.2 \pm 10.4$ & 0.9 & 0.6 & 0.3 \\
\hline Urea $(\mathrm{mg} / \mathrm{dl})$ & $32.4 \pm 7.9$ & $35.82 \pm 7.1$ & $32.35 \pm 8.1$ & 0.2 & 0.9 & 0.19 \\
\hline Creatinine (mg/dl) & $0.79 \pm 0.21$ & $0.75 \pm 0.12$ & $0.78 \pm 0.16$ & 0.7 & 0.9 & 0.7 \\
\hline $\operatorname{ALT}(\mathrm{IU} / \mathrm{L})$ & $73.9 \pm 27.4$ & $104.36 \pm 161.8$ & $27.45 \pm 6.6$ & 0.04 & 0.02 & 0.005 \\
\hline AST (IU/L) & $81.65 \pm 24.6$ & $80.6 \pm 50.2$ & $32.5 \pm 6.5$ & 0.9 & $<0.001$ & $<0.001$ \\
\hline TP (g/dL) & $6.1 \pm 0.5$ & $6.53 \pm 0.76$ & $7.29 \pm 0.35$ & 0.03 & $<0.001$ & $<0.001$ \\
\hline Albumin (g/dL) & $2.2 \pm 0.4$ & $3.12 \pm 0.75$ & $4.55 \pm 0.46$ & $<0.001$ & $<0.001$ & $<0.001$ \\
\hline T.Bil (mg/dL) & $3.3 \pm 0.95$ & $3.92 \pm 5.1$ & $0.7 \pm 0.16$ & 0.8 & 0.04 & 0.006 \\
\hline ALP (IU/L) & $111.6 \pm 95.4$ & $196.16 \pm 164.5$ & $53.1 \pm 14.9$ & 0.04 & 0.03 & $<0.001$ \\
\hline PT (seconds) & $15.10 \pm 2.2$ & $16.09 \pm 4.6$ & $12.03 \pm 1.07$ & 0.5 & 0.02 & $<0.001$ \\
\hline WBC $10^{9} / \mathrm{L}$ & $8.3 \pm 2.1$ & $7.51 \pm 2.5$ & $6.61 \pm 1.7$ & 0.4 & 0.06 & 0.3 \\
\hline $\mathrm{RBC} 10^{12} / \mathrm{L}$ & $4.21 \pm 0.8$ & $3.97 \pm 0.75$ & $4.66 \pm 0.73$ & 0.4 & 0.16 & 0.003 \\
\hline $\mathrm{HB} \mathrm{g} / \mathrm{dl}$ & $10.91 \pm 1.2$ & $10.95 \pm 1.8$ & $12.46 \pm 1.7$ & 0.9 & 0.014 & 0.003 \\
\hline Platelet $10^{9} / \mathrm{L}$ & $139.8 \pm 43.4$ & $128.24 \pm 57.2$ & $324.4 \pm 61.7$ & 0.7 & $<0.001$ & $<0.001$ \\
\hline
\end{tabular}

$p$ 1: LC versus HCC. $\quad p 2$ : LC versus Control. $\quad p 3$ : HCC versus Control.

Table (2): AFP and CLU in the studied groups.

\begin{tabular}{|c|c|c|c|c|c|c|}
\hline & \multirow{2}{*}{$\begin{array}{c}\text { Group I } \\
\text { LC }(n=30) \\
\text { Mean } \pm \text { SD } \\
\end{array}$} & \multirow{2}{*}{$\begin{array}{c}\text { Group II } \\
\text { HCC }(n=50) \\
\text { Mean } \pm \text { SD }\end{array}$} & \multirow{2}{*}{$\begin{array}{c}\text { Group III } \\
\text { Control }(\mathrm{n}=20) \\
\text { Mean } \pm \text { SD }\end{array}$} & \multicolumn{3}{|c|}{$p$-value } \\
\hline & & & & $p_{1}$ & $p_{2}$ & $p_{3}$ \\
\hline AFP (ng/mL) & $21.49 \pm 21.17$ & $2755.6 \pm 6482.5$ & $2.28 \pm 1.33$ & 0.03 & $<0.01$ & $<0.01$ \\
\hline $\begin{array}{l}\text { sCLU ( }(\mathrm{g} / \mathrm{L}) \\
\text { Range }\end{array}$ & $\begin{array}{l}88.3 \pm 30.7 \\
32-150\end{array}$ & $\begin{array}{l}128.5 \pm 24.8 \\
90.2-205\end{array}$ & $\begin{array}{l}110.7 \pm 30.1 \\
60-164\end{array}$ & $<0.01$ & 0.03 & 0.04 \\
\hline
\end{tabular}

$p$ 1: LC versus HCC. $\quad p 2$ : LC versus Control. $\quad p 3$ : HCC versus Control.

Table (3): AFP and sCLU in HCC subgroups.

\begin{tabular}{llll}
\hline & \multicolumn{1}{c}{ Group IIa } & Group IIb & $p$ \\
\hline AFP $(\mathrm{ng} / \mathrm{mL})$ & $3.11 \pm 6370.6$ & $2.6 \pm 6615.9$ & 0.8 \\
Range & $4.6-25250$ & $1.65-36254$ & \\
$\mathrm{sCLU}(\mathrm{g} / \mathrm{mL})$ & $144.07 \pm 24.06$ & $121.8 \pm 22.4$ & 0.003 \\
Range & $100-205$ & $90.2-180$ & \\
\hline
\end{tabular}

Table (4): Sensitivity, Specificity, positive and negative predictive value of AFP and sCLU in HCC group.

\begin{tabular}{lcccc}
\hline & Sensitivity & Specificity & PPV & NPP \\
\hline AFP & $77.3 \%$ & $100 \%$ & $100 \%$ & $83.3 \%$ \\
sCLU & $72.5 \%$ & $92 \%$ & $88.1 \%$ & $77.6 \%$ \\
\hline
\end{tabular}

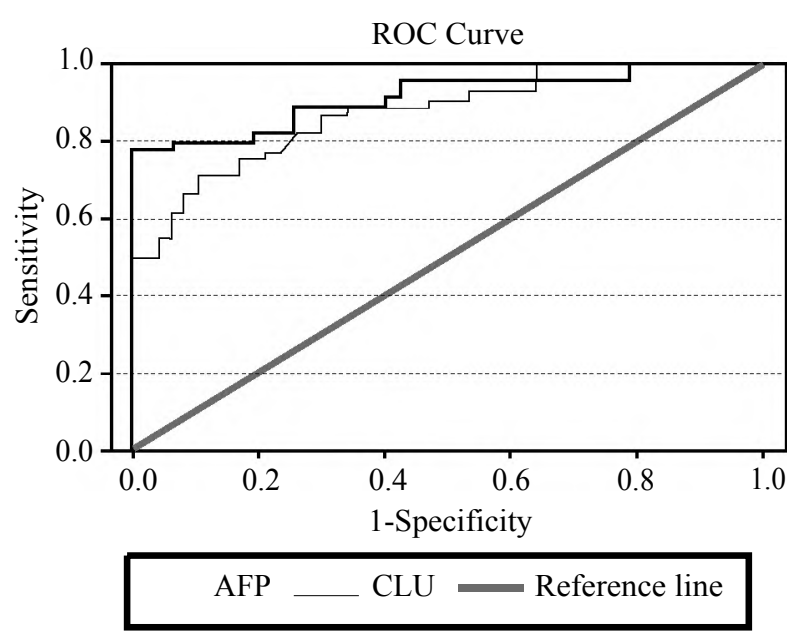

Fig. (1): ROC curve of serum CLU in HCC patients. 


\section{Discussion}

The early diagnosis of HCC is most important due to the poor prognosis of HCC patients. The serum AFP marker is commonly used for HCC diagnosis, but it exhibits a low sensitivity and specificity. So we try to evaluate another diagnostic marker for HCC.

We found higher serum CLU in the HCC group than both control and LC group, denoting its role in carcinogenesis. Such an increase of sCLU was similarly reported in $\mathrm{HCC}$ patients with serum level as well as tissue level. Nafee et al., [12] reported a significant rise of serum CLU in viral related HCC patients, while at tissue level, Kang et al., [17] revealed CLU over expression immunohistochemically in surgically resected HCCs. Furthermore, the increase of CLU level was demonstrated in other tumors; such as bladder cancer [18], colorectal adenocarcinomas [19], and prostate cancer [20]. Our finding leads to hypothesize that CLU secretion occurs from tumor cells in HCC and is reflected in its serum level. This is further supported by the fact that clusterin exists as both an intracellular truncated form and an extracellular heterodimeric secreted glycoprotein, making clusterin the only known chaperone protein to be secreted

Serum CLU showed a significant decrease in the $\mathrm{LC}$ group as regards controls. This may point to a possible protective role of CLU against liver cell fibrogenesis which ultimately ends in cirrhosis. Wang et al., [22] reported a decrease in serum CLU in alcoholic liver cirrhosis and hepatitis B viral liver cirrhosis. Another study reported that up regulation of clusterin during renal injury has a protective response against the development of renal fibrosis [23]

A comparison with AFP, as an HCC marker, our study showed that serum AFP is more sensitive and specific than serum CLU for differentiating HCC from cirrhosis patients, the sensitivity (77.3\% vs. $72.5 \%)$, specificity (100\% vs. $92 \%)$, Moreover, the use of a combined parallel approach improved the diagnostic sensitivity (96.5\%) and negative predictive value $(96.7 \%)$ over the single use of AFP but decreased the specificity to reach $89 \%$ and positive predictive value to be $88.5 \%$, thus improving the sensitivity at the expense of the specificity. On the contrary, Nafee et al., [12] showed that serum CLU is more sensitive and specific than serum AFP for differentiating HCC from cirrhotic patients. Wang et al., [22] also demonstrated that serum CLU with a cutoff level of $50 \mathrm{ug} / \mathrm{ml}$ and serum AFP with a cutoff level of $15 \mathrm{ng} / \mathrm{ml}$, the sensitivity ( $91 \%$ vs. $67 \%)$, specificity ( $83 \%$ vs. $76 \%$ ), positive and negative predictive values (93\% vs. $88 \%$ and $77 \%$ vs. $47 \%$ respectively). The lower cutoff level of AFP $(15 \mathrm{ng} / \mathrm{ml})$ is somehow not applicable in countries with a high prevalence of hepatic diseases especially HCV as in our country. The sensitivity and specificity of the diagnostic biomarker are dependent on the cutoff value above which it is considered positive, and such a cutoff value is affected by the criteria of the studied sample (demographic, clinical, biochemical, method assays and statistical), thus explaining the wide variation in the diagnostic performance of biomarkers in different studies due to different sample criteria.

As regard to the relation of sCLU to $\mathrm{HCC}$ progression, we found a significant increase in the serum CLU level in early stage HCC when compared to late stage HCC $(p<0.003)$, such an increase was not found in serum AFP $(p<0.8)$. There were different reports as regard this point. Lau et al., [24] demonstrated that over expression of CLU increased cell migration and formation of metastatic tumor nodules, but Wang et al., [22] and Nafaa et al., [12] found no significant difference of CLU serum levels between different tumor sizes. In the present study, early stage subgroups of HCC comprised only 15 cases; this can be attributed to the rarity of such patients due to delayed diagnosis of HCC. We cannot deny the possibility of a random effect due to the small size of this subgroup rendering it difficult for establishing reliable statistical results that could be applied in clinical use. Therefore, we recommend investigating CLU level on a larger cohort to ascertain such an association. But a possible explanation may be that the CLU increase in the late stages is directed to the nuclear form rather than the secreted form. Moreover, the complex nature of CLU and its multiple isoforms not only in tissues but also in serum should be considered. Pucci et al., [25] explained the diversity of CLU function in colorectal carcinoma by a shift in the pattern of its isoform production. Also, another study pointed to the importance of measuring CLU isoforms over that of total serum level, when they demonstrated the increase of some isoforms and the decrease or absence of others in colorectal carcinoma [26].

\section{Conclusion:}

We can conclude that serum AFP did better than serum CLU in all aspects of diagnostic performance for diagnosing HCC. Notably, a combination of sCLU and AFP for HCC diagnosis would increase the sensitivity which is required to screen 
high risk populations such as chronic hepatitis $\mathrm{C}$ patients. So serum CLU levels should be a useful potential biomarker for HCC diagnosis.

\section{References}

1- KEW M.C.: The role of cirrhosis in the etiology of hepatocellular carcinoma. J. Gastrointest. Cancer, 45: 12-21, 2014.

2- CHEN J.G., ZHU J., ZHANG Y.H., et al.: Cancer survival in Qidong between 1972 and 2011: A population-based analysis. Mol. Clin. Oncol., 6: 944-54, 2017.

3- MATSUURA K. and TANAKA Y.: Host genetic variations associated with disease progression in chronic hepatitis C virus infection. Hepatol. Res., 48: 127-33, 2018.

4- TONG H.V., BOCK C.T. and VELAVAN T.P.: Genetic insights on host and hepatitis B virus in liver diseases. Mutat. Res. Rev. Mutat. Res., 762: 65-75, 2014.

5- HASSAN M.M., ZAGHLOUL A.S., El-SERAG H.B., et al.: The role of hepatitis $C$ in hepatocellular carcinoma: a case control study among Egyptian patients. J. Clin. Gastroenterol., 33: 123-6, 2001.

6- Egyptian Ministry of Health: Egyptian Ministry of Health Annual Report, 2007.

7- ALBERTI A., VARIO A., FERRARI A., et al.: Chronic hepatitis $\mathrm{C}$-natural history and cofactors. Aliment. Pharmacol.Ther., 22 (2): 74-8, 2005.

8- SOUZA A.F., PACE F.H., CHEBLI J.M., et al.: Insulin resistance in non-diabetic patients with chronic hepatitis $\mathrm{C}$ what does it mean? Arq. Bras. Endocrinol. Metab., 55 (6): 412-8, 2011.

9- CHIARAMONTE M.G., DONALDSON, et al.: An IL13 inhibitor blocks the development of hepatic fibrosis during a T-helper type 2-dominated inflammatory response. J. Clin. Invest, 104: 777-85, 1999.

10- CUERVO A.M. and WONG E.: Chaperone-mediated autophagy: roles in disease and aging. Cell. Res., 24: $92-$ 104, 2014.

11-JONES S.E. and JOMARY C.: Clusterin. The international journal of biochemistry \& Cell Biology, 34 (5): 427-31, 2002.

12- NAFEE A.M., PASHA H.F., ABD El-AAL S.M., et al.: Clinical significance of serum clusterin as a biomarker for evaluating diagnosis and metastasis potential of viralrelated hepatocellular carcinoma. Clin. Biochem., 45: 1070-4, 2012.

13- ZHONG J., YU X., DONG X., et al.: Clusterin-mediated invasion in hepatocellular carcinoma cells. Therapeutic
Role of Meloxicam Targeting Secretory Oncol. Lett, 15 7191-9, 2018

14- ZHENG W., YAO M., SAI W., et al.: Diagnostic and prognostic significance of secretory clusterin expression in patients with hepatocellular carcinoma. Tumour. Biol., 37: 999-1008, 2016.

15- ZHENG W.J., SAI W.L., YAO M., et al.: Down-regulated clusterin expression enhances sensitivity of hepatoma cells to anti-cancer drugs. Zhonghua Gan Zang Bing Za Zhi, 23: 844-8, 2015

16- BRUIX J. and SHERMAN M.: Management of hepatocellular carcinoma. AASLD practice guidelines: Hepatol., 9-13, 2010.

17- KANG Y.K., HONG S.W., LEE H. and KIM W.H.: Overexpression of clusterin in human hepatocellular carcinoma. Human Pathology, 35 (11): 1340-6, 2004.

18- STEJSKAL D. and FIALA R.R.: Evaluation of serum and urine clusterin as a potential tumor marker for urinary bladder cancer. Neoplasma, 53 (4): 343-6, 2006.

19- KEVANS D., FOLEY J., TENNISWOOD M., SHEAHAN, et al.: High clusterin expression correlates with a poor outcome in stage II colorectal cancers. Cancer Epidemiology and Prevention Biomarkers, 18 (2): 393-9, 2009.

20- MIYAKE H., MURAMAKI M., FURUKAWA J., KURAHASHI T., et al.: Serum level of clusterin and its density in men with prostate cancer as novel biomarkers reflecting disease extension. Urology, 75 (2): 454-9, 2010.

21- CHI K N., SIU L.L., HIRTE H., HOTTE S.J., et al.: A phase I study of OGX-011, a 2'-methoxyethyl phosphorothioate antisense to clusterin, in combination with docetaxel in patients with advanced cancer. Clinical Cancer Research, 14 (3): 833-9, 2008.

22- WANG Y., LIU Y.H., MAI S.J., et al.: Evaluation of serum clusterin as a surveillance tool for human hepatocellular carcinoma with hepatitis B virus related cirrhosis. J. Gastroenterol. Hepatol., 25: 1123-8, 2010.

23- JUNG G.S., KIM M.K., JUNG Y.A., et al.: Clusterin attenuates the development of renal fibrosis. Journal of the American Society of Nephrology, 23 (1): 73-85, 2012.

24- LAU S.H, SHAM J.S.T., XIE D., TZANG C.H., et al.: Clusterin plays an important role in hepatocellular carcinoma metastasis. Oncogene, 25 (8): 1242-50, 2006.

25- PUCCI S., BONANNO E., PICHIORRI F., ANGELONI C. et al.: Modulation of different clusterin isoforms in human colon tumorigenesis. Oncogene, 23 (13): 2298 304, 2004

26- RODRIGUEZ-PINEIRO A.M., DE LA CADENA M.P., LOPEZ-SACO Á., et al.: Differential expression of serum clusterin isoforms in colorectal cancer. Molecular \& Cellular Proteomics, 5 (9): 1647-57, 2006. 


\section{قياس مستوى الكلسترين بالدم كدلالة لتشخيص سرطان الكبد فى مرضى الألتهاب الكبدى سلكى سلى المزمن}

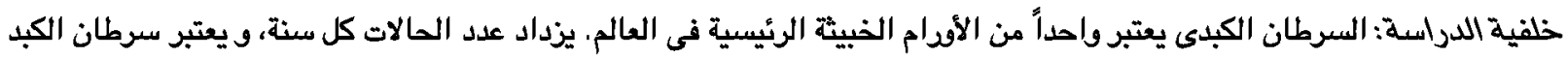

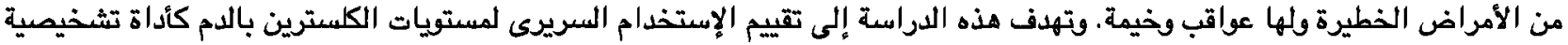

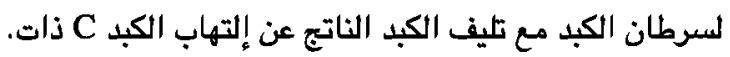

الآفرد وطرق البحث: أجريت هذه الدراسة على . .1 شخص، +1 مريض و.ب من الأصحاء كمجموعة ضابطة، مجموعات المرضى مقسمة

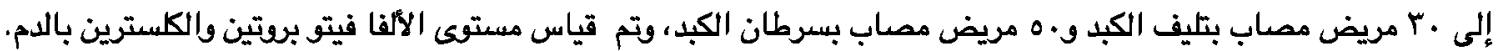

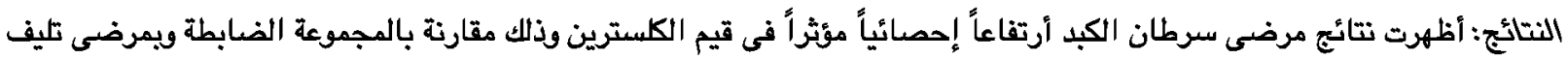

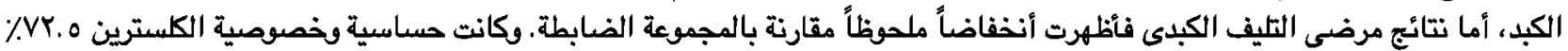

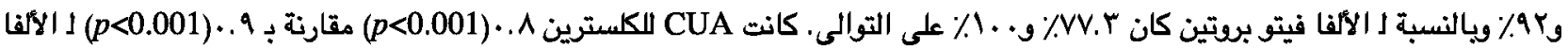

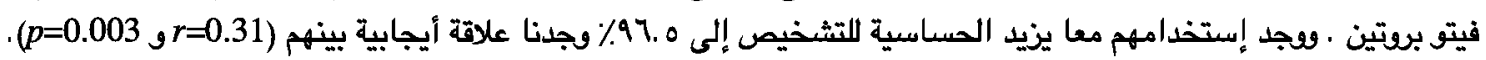
الأستتاج: إستخدام مستوى الكلسترين علامة مفيدة لتشخيص سرطان الكبد . 